\title{
CONFLITO E PODER NAS ORGANIZAÇÕES
}

Há muito dedicando suas investigações à análise do exercício do poder e do surgimento de conflito nas organizações, a Professora Cristina Amélia Carvalho, do Propad/UFPE foi, inúmeras vezes, perguntada quais as leituras fundamentais sobre o tema. Essa seção traz a possibilidade de disseminar essa resposta. Entretanto, seu formato não permite abarcar todas as obras relevantes publicadas sobre conflito e poder nas organizações. Assim, muitos textos, como os escritos por Weber e Foucault, apesar de importantes, não são indicados. As cinco referências que se seguem, recolhidas na panóplia da literatura especializada, possibilitarão compreender diferentes enfoques, abordagens e construções explicativas acerca do tema.

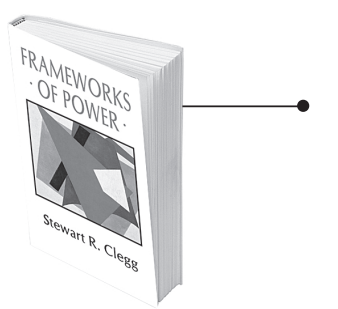

FRAMEWORKS OF POWER Stewart Clegg. London /Newbury /New Delhi : Sage, 1989. 297 p.

Este livro de Stewart Clegg é uma das mais amplas digressões pelas diferentes abordagens sobre o poder e suas derivações nas organizações. Remontando às contribuições dadas por precursores como Hobbes e Maquiavel, o autor refaz os passos das construções explicativas que lhes sucederam, tanto na ciência social anglo-saxônica como em aportes oferecidos pelos teóricos críticos alemães da Escola de Frankfurt, até os mais recentes sociólogos da escola francesa. Resgatando tudo o que de importante já se escreveu sobre poder, controle e conflito nas organizações, Clegg não construiu uma obra historiográfica, mas uma análise profunda das diferentes contribuições.

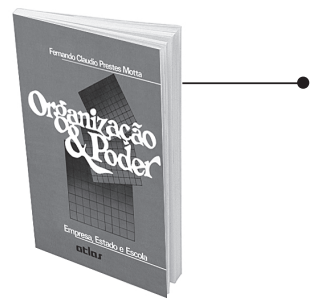

ORGANIZAÇÃo \& PODER: empresa, Estado e escola Fernando C. Prestes Motta. São Paulo : Atlas, 1990. 143 p. Este livro, de autoria de um colega que há pouco nos deixou, foi e ainda é um importante contributo no caminho de uma literatura especializada, construída a partir de reflexões e pesquisas teóricoempíricas no Brasil. Neste trabalho, Prestes Motta discute principalmente a estrutura da burocracia, a dominação inerente a esse modelo de organização social. Em particular, é dedicada especial atenção ao poder e às estratégias de controle da tecnoburocracia. Esta obra é um libelo pela democratização do saber sobre a burocracia e seus efeitos na sociedade e, ainda, pela capacidade do homem de dominar as estruturas que ele próprio construiu, começando pelo conhecimento sobre elas.

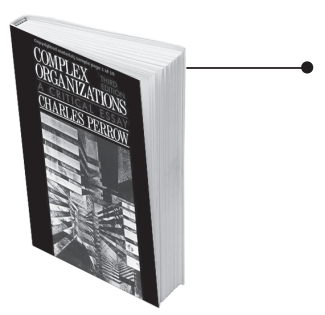

COMPLEX ORGANIZATIONS: a critical essay Charles Perrow. (Introduction to Modern Society series). Glenview / Dallas / Oakland /Palo Alto /Tucker / Abingdon: Scot, Foresman and Company, 1972. 224 p.

Um livro clássico no estudo das organizações, nele, Perrow apresenta uma ampla interpretação das organizações complexas na sociedade moderna, fazendo uma revisão das grandes perspectivas de análise organizacional. No enfrentamento que trava com a abordagem de relações humanas, aponta sua inutilidade para a compreensão da natureza das organizações; questiona, igualmente, a perspectiva orgânica e o modelo que percebe as organizações como sistemas naturais com capacidade de adaptação às mudanças do ambiente. Em contraposição, propõe um desenho das organizações moldado no modelo weberiano e, por extensão, põe na ordem do dia o poder como determinante fundamental da existência das organizações.

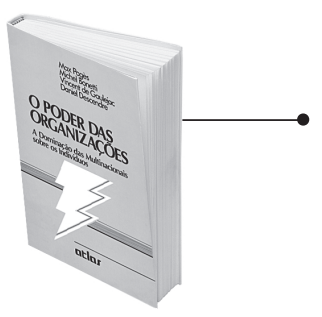

O PODER DAS ORGANIZAÇõES Max Pagès, Michel Bonetti, Vincent de Gaulejac e Daniel Descendre. São Paulo : Atlas, 1993. $234 \mathrm{p}$.

Pagès e sua equipe de pesquisadores escreveram esta obra, que rapidamente se tornou uma leitura imprescindível para todos os que desejam entender o exercício do poder nas organizações, o controle que elas exercem sobre os homens e os conflitos que são gerados em seu interior. O título original, L'emprise de l'organisation, já descortinava a idéia que conduziu a investigação dos autores: as organizações são loci de dominação ideológica, psicológica, econômica e política sobre os indivíduos. Muitos bons textos foram produzidos a partir do mesmo ponto de partida, mas este pode ser considerado um marco inicial e, por isso, é leitura obrigatória.

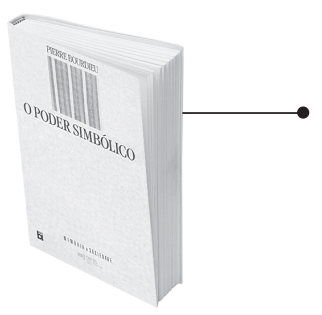

O PODER SIMBÓLICO Pierre Bourdieu. 4ª ed. Rio de Janeiro : Bertrand Brasil, 2001. 322 p.

A leitura do livro do sociólogo francês Pierre Bourdieu exige que outras leituras sobre o tema tenham sido feitas anteriormente, pois só assim será possível perceber a extensão das contribuições que o autor oferece em seu texto e o significado inovador de muitas das noções utilizadas. A discussão sobre o poder e suas derivações tem, na obra de Bourdieu, uma abordagem que os remete ao plano da produção simbólica e lá os disseca. No mundo de hoje, em que os símbolos que os indivíduos carregam têm poder de definir suas posições no campo social, a leitura deste livro é, de fato, imprescindível. 